Fig. 8. Hydrophorus amplectens sp. nov. side of abdomen of male.

$9 . \quad$ " canescens Wheeler, front femur and tibia of male.

10. “ breviseta Thomson, front tibia of male.

11. " " " upper view of tip of left middle tarsus, male.

12. " agalma Wheeler, upper view of tip of middle tarsus, male.

13. " amplectens sp. nov., part of front femur and tibia of male,

14. “ philombrius Wheeler, front femur and tibia of male.

15. Diostracus olga sp. nov., side view of male.

16. " " " " front view of head of male.

17. " “ " “ a antenna of male outer side.

18. " " " w wing of male.

\title{
NOTES ON THE DIPTEROUS GENERA PROPOSED BY BILLBERG IN HIS ENUMERATIO INSECTORUM ${ }^{1}$
}

My attention has been recently called to this work by Mr. Henry L. Viereck who was endeavoring to locate some genotypes in the Hymenoptera. A copy of this rare book was presented to the library of the Boston Society of Natural History by Mr. Samuel H. Scudder. In looking over the pages (112-123) pertaining to Diptera I find the following generic names:

"Tichodartha Eg. 2-Mosillus Ltr.,-Musca Ol." No species are mentioned.

Under " 1 Divis. alis divaricatis, 1 subdivis. antennis capite medio brevioribus," page 118, appears the following:-

"Blera Eg.-Eristalis Flln.-Syrphus Fbr. Ltr.-Musca Ol. fallax Svec. Linn. cœmiteriorum Svec. Linn."

Recognizing Cynorhina Will. (1886) as has been done by Verrall, (Brit. Flies, VIII, 590) Musca fallax Linn. becomes the type of Blera, or considering Cynorhina to be a synonym of Criorhina Meigen, 1822, and ignoring Perthesilea Meigen, 1800, Criorhina also becomes a synonym of Blera. Musca camiteriorum Linn. is a doubtful species considered by some to be the same as Chrysogaster solstitialis Fall.

"Dones Eg.-Doros Mgn. III-Syrphus Auct. Pler.-Scaeva Flln.-Musca el [OI].

1 Enumeratio Insectorum in Museo, Gustav Johann Billberg. [Holmiæ] Typis Gadelianis Gadel, 1820.

Eg. "Auctor hujus operis." 
*abdomine elongato depressiusculo festivus Srec. Linn.
** abdomine clavata

conopseus__ _

Musca festivum Linn. is a Chrysotoxum Meig. 1803, and Syrphus conopseus Fabr. is the type of the genus Doros Meig, 1803.

" 2 Divis. Alis incumbentibus. 1 subdiv. antennis longitudine capitis vel ultra. Calicera Eg.-Callicera Mgn. Pnz. Ltr.-Bibio Fbr.-Syrphus Rss."

No species mentioned.

Under "11 Natio Dolichopides Palpis proboscide brevioribus; alis incumbentibus. Calomya Eg.-Callomya Mgn. Flln.Dolichopus Fbr. Ltr. Wlck.-Musca Ol."

No species mentioned.

Under "13 Natio, Asilides. Capite transverso thoraci collo exserto adnexo. 1 Divis. Tarsis pulvillis duabus."

"Laphyra Eg.-Laphria Mgn. Ill. Ltr. Fbr. Flln.-Erax Scp.Asilus auct. Pler.

gibbosa Svec. Linn.

flava

ephippium Fbr.

gilva Svec. Linn

marginata

rufipes - Flln."

All of these belong to the genus Laphria Meigen 1803.

"19 Natio Culicides Antennis gracilibus, capite longioribus, $\sigma^{\text {" }}$ valde plumosis l, verticillato-pilosis; ocellis nullis."

"2 Divis. Alis deflexis Cnips Eg. - Culicoides Ltr."

Of the above names only Blera seems to be of any special importance.

C. W. Johnson.

\section{ANOTHER IMPORTED CLOVER WEEVIL.}

Among the Phytonomus received for examination this winter I find specimens that belong to a species apparently not hitherto reported from America. This latest accession to the list of our clover and alfalfa enemies is Phytonomus? meles Fab.

Specimens have been identified from the following localities: Albany, N.Y., 9 July 1908 bred from red clover (Dr. E. P. Felt); West Point, N. Y., W. Robinson, 28 April 1908 (coll. Am. Mus. Nat. Hist.); Brooklyn, N. Y. (C. Schaeffer); Westchester Co., N. Y. (Schaeffer); Rockaway "washup" (Schaeffer); Rockaway Beach, N. Y. (E. A. Bischoff); New Haven, Ct., 28 May 1910 and Hamden, Ct., 16 May 1910 (A. B. Champlain); Framingham, Mass., 5 May 1909 (C. A. Frost); Ramsey, N. J., 31 May 1908 (Schaeffer); Hewit, N. J. (Schaeffer); Rahway, N. J., 23 July (Bischoff); Newfoundland, N. J., 30 May (Bischoff); Lake Hopatcong, N. J., 30 May (J. A. Grossbeck).

It has much the same color as the alfalfa leaf-weevil ( $\boldsymbol{P}$. posticus Gyll.) but the scales are cleft to the base as in $P$. nigrirostris and the thorax is much wider than in either of these species.

E. G. Titus.

Mr. E. A. Bischoff (in litt. 18 Apr., 1911) states that this is the P. Castor of Smith's Cat. Ins. of N. J. 

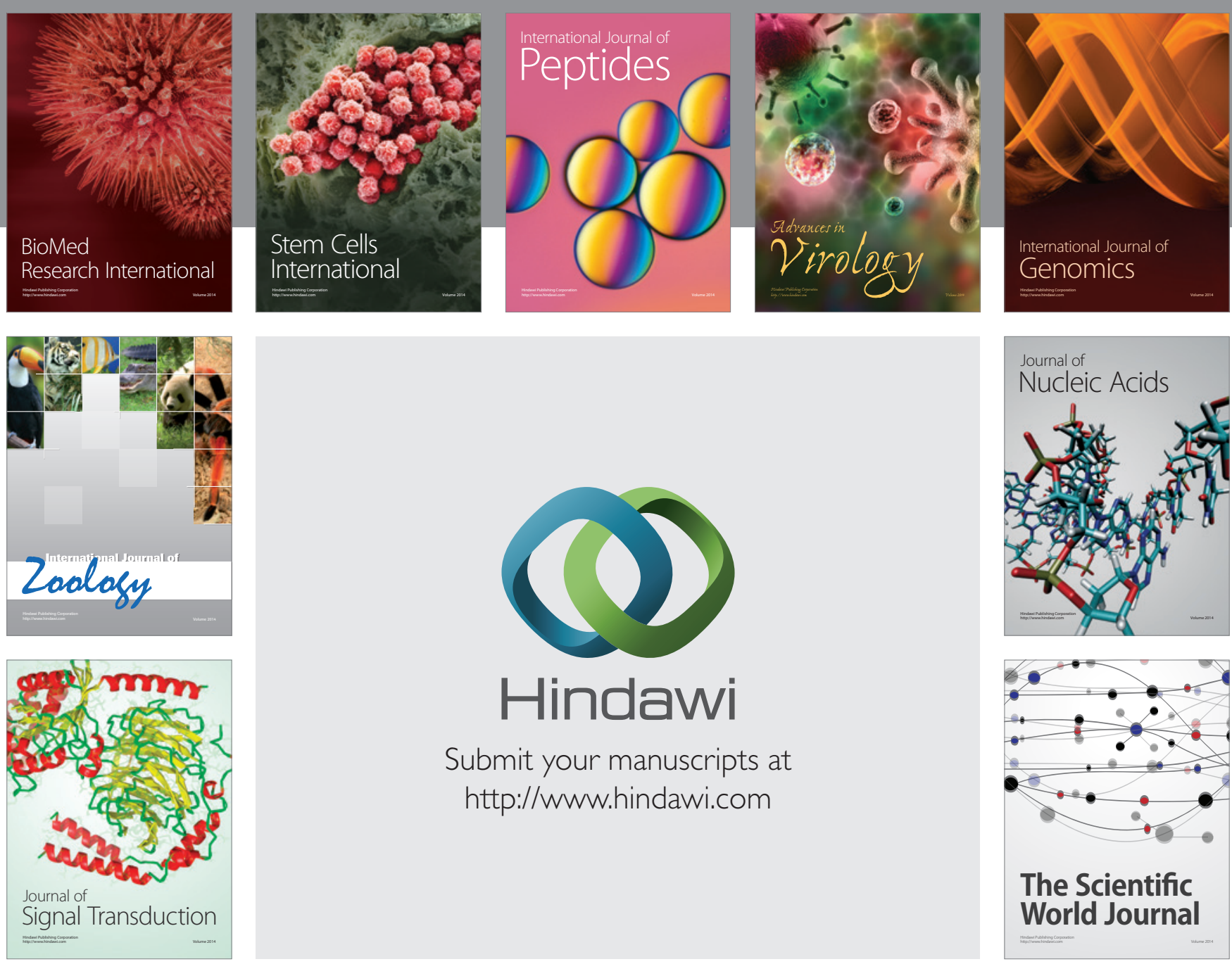

Submit your manuscripts at

http://www.hindawi.com
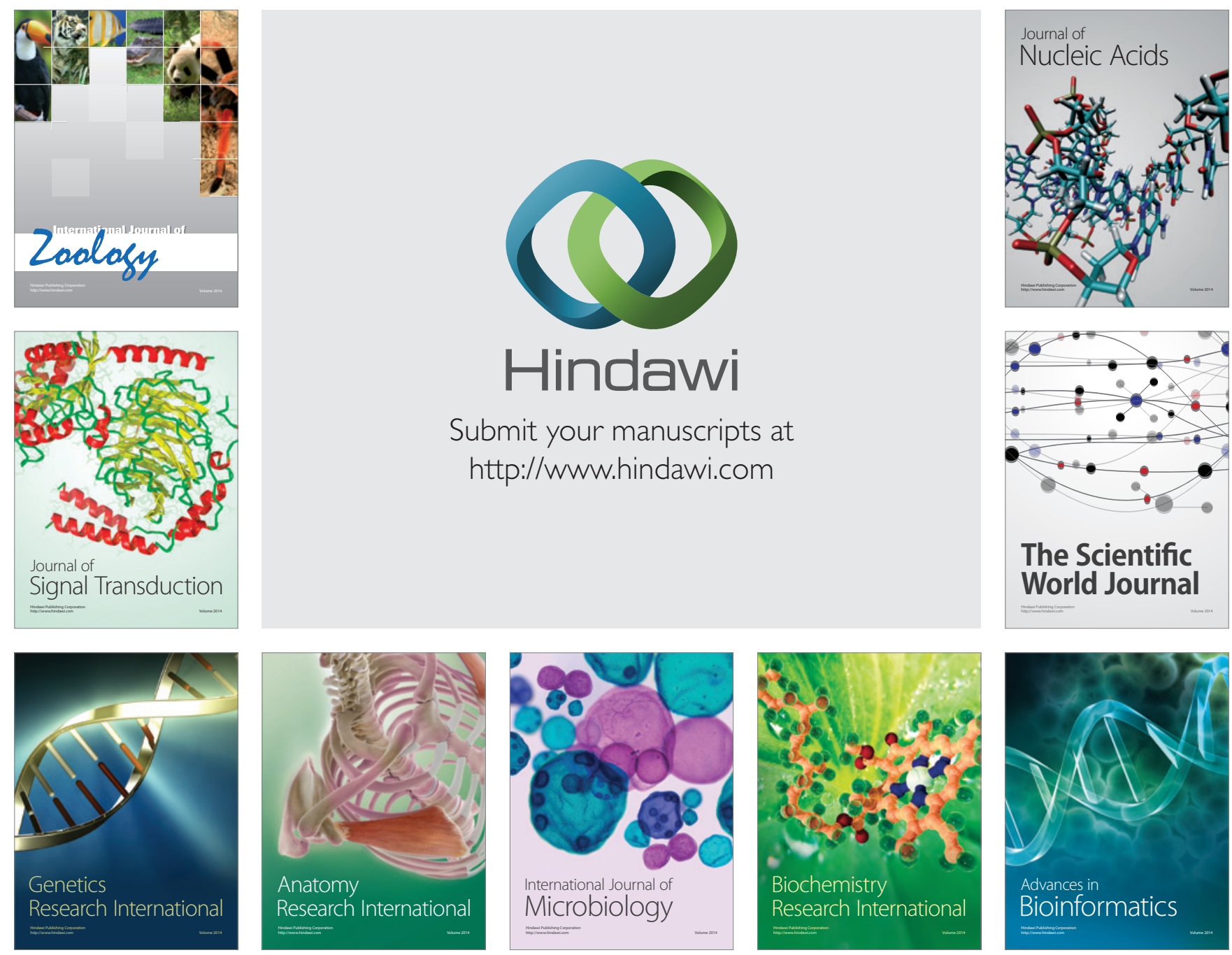

The Scientific World Journal
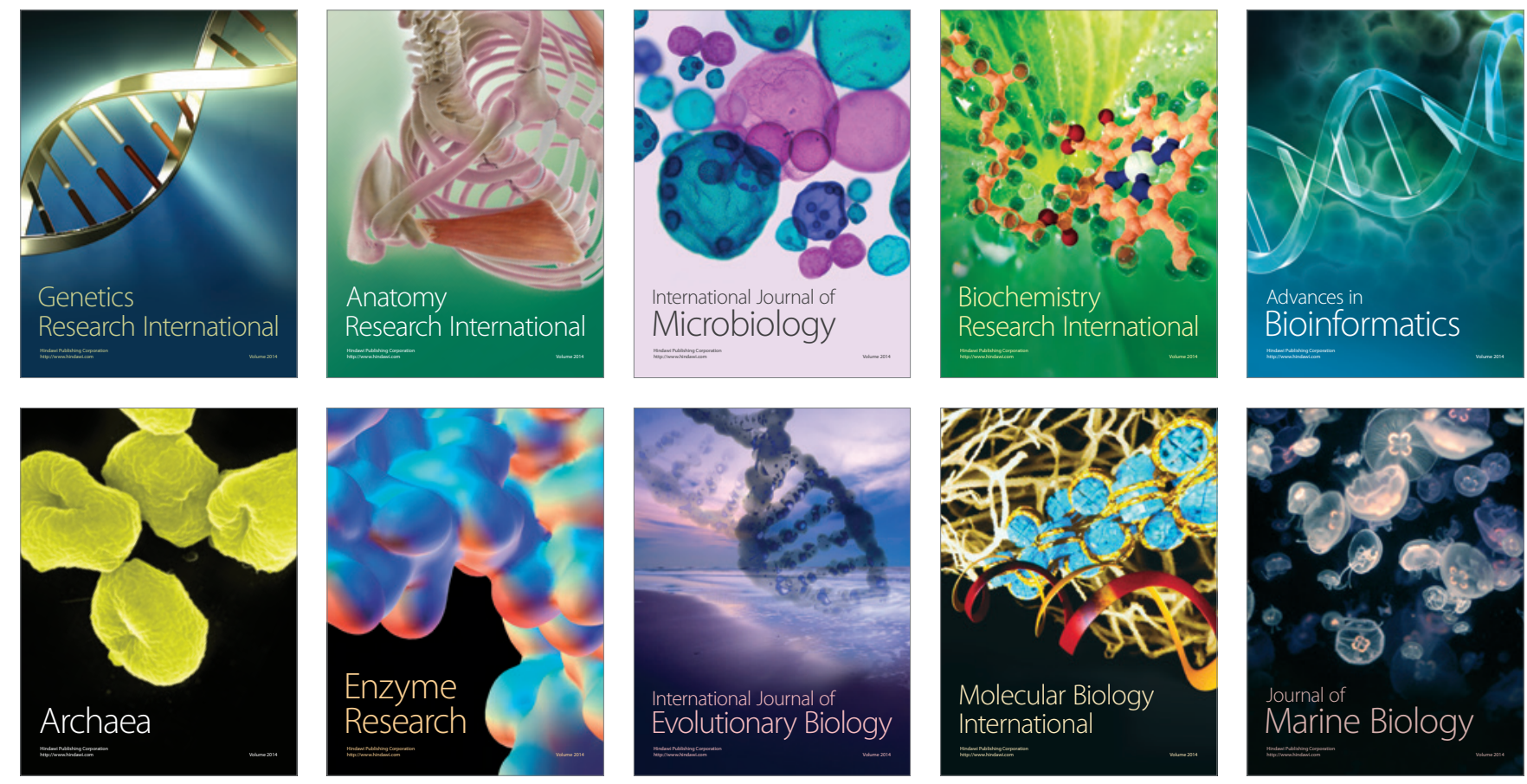